\title{
Singing and Sounding the Sacred - the Function of Religious Songs and Hymns in the Public Sphere
}

\author{
Elsabé C. Kloppers \\ kloppec@unisa.ac.za
}

\begin{abstract}
Hymns are commonly sung in the public space of worship. They often also function in other public as well as private spheres. Religious singing in public spaces forms bridges between personal faith, the church, and public Christianity, while at the same time also forming bridges to a pluralist, secular, and post-secular society. I depart from the premise that the singing of hymns in the public sphere constitutes a form of religion lived in public. When the singing is reflected upon and discussed in public, also in social media, it can be seen as a form of public theology. Aspects of the reception histories and narratives of hymns, functioning in the wider public sphere in various countries and in various contexts and times, are discussed with regard to the possible functions that the singing could fulfil in these contexts. It is shown that hymnody forms a part of the beliefs, self-concepts, values, symbols, identities, ideologies, instruments of power, sets of myths, and the collective cultural memory of people.
\end{abstract}

Keywords: Religious songs, hymns, hymnology, lived religion, religious singing in public, reception histories, protest songs, narrative method

\section{Introduction}

Hymnology is about studying every aspect of hymns and songs - from the biographies, backgrounds, and contexts of text writers and composers to the reception histories or Wirkungsgeschichte of hymns; from studying language, imagery, metaphors, and theology in texts to analyzing tunes and the relation- 
ships between texts and tunes; and from determining the liturgical functions of hymns to uncovering the influence of hymns in the wider public sphere. Maintaining that singing hymns in the public sphere is an important aspect of lived religion or lived faith in public, I discuss hymn singing in various times and in various contexts, reflecting on possible reasons for singing hymns in public, the function it could fulfil, and possible meanings that can be attributed to the singing.

\section{Reflecting on Singing Hymns in the Public Sphere}

The discipline of hymnology, focusing on hymnody and its function in public worship as well as its function in non-liturgical, public contexts, is informed by perspectives from all disciplines of theology and also by perspectives from cultural studies, religious studies, sociology, history, ethnology, and many other disciplines. A big roundabout or traffic circle might be a good metaphor: The discipline of hymnology brings the traffic between the theological disciplines together, and it keeps the traffic between the theological disciplines and other disciplines in the public sphere flowing. It is focused on hymns and songs that are cultural offerings reflecting religious views, works of art that constantly provide for new possibilities to be sounded, to be reflected upon, and to be discussed in connection with a diversity of disciplines.

The theologia prima - the first theology - is practiced in worship, in the actions of the liturgy, such as singing and praying. In reflecting theologically on these practices, a bridge is formed between lived faith and theology. The singing of hymns in the public sphere constitutes a form of public religion. When the singing is reflected upon and discussed in the public media - also in social media - it can be seen as a form of public theology (Bubmann 2017:152). A reflection on lived faith and religion lived in the public sphere, can be approached from a diversity of methods. In the study of the reception histories and influences of hymns, which is the focus of this article, biographical experiences, histories, and contingencies play an important role. Söffner (2018) calls for a stronger emphasis on narrative as a method of research in social and cultural studies - motivating it with reasons that are relevant also for the field of hymnology. He argues that meaning is fixed only (reasonably) in fairly narrow specialist areas and that in reality the 
lives of people consist of coincidences, contradictions, vagueness, halfknowledge, inconsistency, and repression. What is often regarded as 'merely contingent' from the point of view of the more 'exact' sciences, are the notions that could be highly relevant for the researcher of narratives: Random encounters, things happening by chance, personal arbitrariness, unexpected situations, conflicts, the absurd course of events, or the special 'turns of life'. Due to their functioning in time, narratives bring meaning and causality into a context that is closer to life than the contexts on which the more 'exact sciences' are focused ${ }^{1}$. In the narrative, time is organized as movement and flow and not as a fixed structure. Söffner (2018) argues that methodos points to 'road' - a way to go - rather than indicating a fixed map for executing exact actions. His concept of 'erlebende Unterwegssein' - experiencing life while being on the move through life - is relevant for research on lived religion. The stories of people, their emotions, their experiences with sacred music, and the singing of hymns, function as space for resonance as well as space for memories. The influence on people and how they symbolize or create individual or corporate identity, form part of a bigger picture of how people live their religion in various contexts in the public sphere.

The vivid description by Kurzke (2010:189) of the role of Grosser Gott, wir loben dich (Holy God, we praise your Name) at the Corpus Christifestivities in the Roman Catholic Church is a good example. He argues that this specific hymn is sung with such fervor, that one could believe that the hymn is 'intrinsic catholic' (Kurzke 2010:189). At first glance his description might seem to be a subjective impression only, but it provides for important views and experiences that, combined with other observations, give the possibility for generalizations and further research (Fischer 2007:1) ${ }^{2}$.

Söffner (2018) admits that narrative methods could lack verifiability but argues that one can control narrative experience by balancing it with interpretiveunderstanding and causal-explanatory procedures, similar to accompanying a journey keeping the eye also on the map. He refers to narrating (erzählende) philosophers such as Kierkegaard, Sartre, and Camus, as well as theorizing narrators, such as Dante and Proust, who have shown that observation, contemplation, interpretation, analysis, and description are compatible with narrative processes and thus can be converted into a mode of mutual, communicative control.

2 I am using Kurzke's description as point of departure and argue that when this hymn was introduced in the Afrikaans language in a new hymnal for the Dutch 
A hymn is a cultural product that represents meaning and faith. It reflects possibilities for truth, negotiates conflict zones, forms identity, and reflects and influences views of life and views of the church (Neufeld 2006). It thus forms the theologies of people, their views of God, and their views of society. The personal narratives and experiences of one person can be linked to that of others, creating a bigger picture of the use and influences of a song or hymn over time and in various other contexts, thus forming history in the broadest sense.

\section{Hymns in the Public Sphere in Various Contexts and in Various Times}

Hymns are part of the cultural offerings representing Christian symbols in the wider public sphere - even if people might think they are confined to public worship. They are (still) part of a secular and post-secular culture, where the Christian religion has not returned (cf. Graf 2004) as it is often claimed, but from where it has never disappeared. Not only has Christianity shaped the Western culture - it continues to shape the Western culture in a multitude of ways not always consciously observed (Holland 2019; De Groot 2020:9-20). After big disasters or tragic incidents, people often gather in public to pray and sing, sometimes as part of a formal commemorative event, and often also in an informal ritual. The people spontaneously singing hymns as flames tore through the roof of the historic Notre Dame cathedral in April 2019, was a touching example of sounding the sacred in the public sphere of a metropolis such as Paris (cf. eg. Présente 2019). The singing was not only a lament for the loss of a valuable symbol of the Christian faith, but also a prayer voicing hope - that all is not lost.

The praxis of singing in various contexts is often ideology-laden, influenced by power, politics, culture, gender, race, and money. Every aspect of religion lived by singing hymns and religious songs - as all other forms of lived religion - has to be approached with a hermeneutic of suspicion. Reflecting on histories of singing or using hymns and songs in the public

Reformed Churches in 1978, it immediately was so popular that the people singing it, never would have thought of it as being 'intrinsic catholic'; they certainly accepted it from the start as a hymn 'meant for protestants' (Kloppers 2019:117-119). 
sphere, the possible functions that it could fulfil, and the meanings it may represent, I will show how hymns and songs meant for worship, praise, and for expressing faith, have been used and are still used for political, nationalist, and ideological causes.

\section{Metrical Psalms and Hymns in the Context of Afrikaans-Speaking People: $20^{\text {th }}$ Century}

In earlier research I have investigated the ideology-laden context and praxis of hymnody among Afrikaans-speaking people and related it to concepts and theories of religious and cultural identity, processes of (self)perception and (self)interpretation, and the influence of these aspects on the tradition and identity of certain Afrikaans-speaking people. Working from the theoretical perspective of the collective cultural memory of a people (Assmann 1991:1330), I critically analyzed the identity-giving and political role of certain Psalms and hymns - especially those sung on the Day of the Vow (Geloftedag) - a day commemorating the Battle of Blood River on December 16, 1838 (cf. Marx 1998 for interesting 'outsider' perspectives). I argued that singing these hymns and Psalms functioned on the level of a civil religion (Moodie 1976; Bosch 1984) and contributed to keep alive the grand narrative of God protecting 'his people' ('sy volk'). This research also forced me to reflect critically on my own lived experiences of singing hymns in various circumstances and the formative influence it had in my life (Kloppers 2002).

\section{Psalm Singing in Scotland: $20^{\text {th }}$ Century}

In later research I connected the perspectives from South Africa with views held in Scotland and showed that nationalism, stimulated by the singing of hymns and Psalms, is not limited to the South African context. I referred to the story of the new Scottish MPs, on their way to Westminster after a landslide victory in 1922, who boarded the train, while on the platform a large group of people sang metrical Psalms (Kloppers 2012:166). This was certainly done for nationalist reasons: To encourage the politicians to stand up for Scotland, knowing that God and God's word, in the form of God's song, were with them. 


\section{Te Deum Laudamus: $4^{\text {th }}$ to $21^{\text {st }}$ Century}

The Te Deum Laudamus is one of the three oldest hymns of the Christian tradition (Franz 2017:423) ${ }^{3}$. Its reception history or Wirkungsgeschichte is an interesting example of a hymn used in the liturgy and in the public sphere, thus having attributed a diversity of meanings to it. Originally being a great hymn of praise to God the creator, sung during matins in monasteries on Sundays, it also developed to be used in medieval times as a hymn of thanksgiving during the election of a pope and the consecration of bishops. Later it also became a hymn of praise in the courts of kings and in state ceremonies. God's glory was not in focus anymore, but the glory of a ruler or a person in power - it was therefore used for political purposes. Sung after battles as praise for victories, it also played a role in military contexts - such as the Te Deum for the battle of Dettingen, composed by George Frideric Handel in 1743 (Franz \& Schäfer 2019:15). The Te Deum is still used in the liturgies of certain churches, but (as far as I know) it does not fulfil any political function anymore. Interestingly the bells of churches are often tuned to the incipit (the first notes - e-g-a) of the Gregorian Te Deum - thus sounding the hymn in the public sphere. A translation of the Te Deum Laudamus in German, the popular hymn Großer Gott wir loben dich, was used by the National-Socialist (Nazi) Party in Germany as a hymn at their rallies (Franz \& Schäfer 2019:21). In that context the singing probably gave the people the assurance that God was on their side.

\section{Ein neues Lied wir heben an (Martin Luther 1523)}

Two Augustinian friars who resisted the power of the mighty Roman Catholic Church, were burnt to death on the stake in Brussels on July 1, 1523. In a time before newspapers, Facebook, and Twitter, Martin Luther used the general means of mass communication to make it known: That of singing in the public sphere. Travelling singers used the standard marker, 'We sing a new song', to indicate that a news bulletin was to follow. That was also the marker that Luther used for his very first song - followed by the news of what had happened in Brussels and interpreting the events as something that

3 The Te Deum is regarded as a living part of (Western) culture. This can be deduced from Brödel's reference to officials in the GDR who, due to the fact that they did not have sufficient training in the humanities in the early years of the GDR, had asked about the meaning of Te Deum (Brödel 2019:63). 
'God has done'. It was meant as protest but also to encourage the faithful: If the death of the martyrs appeared to be a tragedy, it actually was a victory, a triumphant witness for the 'new faith'. People heard the song, joined in, and the news spread like wildfire (Klek 2012:24). The song depicts the martyrs singing hymns of praise (in the public sphere) while dying on the stake. By singing this song of Luther, their hymns of praise were extended and taken even further after their death, spreading over the world. Singing became the strongest form of protest against an institution that shamelessly abused its powers - it disarmed the mighty. Seen as the 'sharpest weapon', it was no surprise that singing on the streets in cities such as Hildesheim (an episcopal city), was prohibited by law in 1524 and 1531 (Klek 2012:24). The 'Protestants' would then go on singing at the gates of the city.

Luther's Psalms functioned as protest songs against the Roman Catholic Church, also in Magdeburg. In May 1524, the mayor came from early mass and encountered a gathering of people. The attraction in front of the imperial monument was a 'poor old cloth maker' who offered a leaflet with two Psalms by Luther, singing them and encouraging the people to sing along. The mayor ordered his immediate arrest. About 200 citizens protested at the town hall and obtained his release on the same day. Shortly thereafter citizens applied for admission that 'Protestant sermons' be held in the city, which was allowed. Through these actions, Magdeburg became the first city in Northern Germany to become Protestant (Mager 1986:27-28).

\section{Ein feste Burg ist unser Gott: Martin Luther $-16^{\text {th }}$ to $20^{\text {th }}$ Century}

An example of a hymn working in a diversity of spheres, is Ein feste Burg ist unser Gott by Martin Luther. Based on Psalm 46, Luther described it as 'a hymn of thanks of the nation of Israel, against the rage and rave of all kings and heathen people' (Fischer 2012:29). Focusing on trust in God, the hymn, with its imagery of fortresses and weaponry, soon found its way to the public sphere as a song of war against confessional opponents and political enemies such as the Turks. In Des Knaben Wunderhorn - the collection of old German folk poems and songs of Clemens Brentano and Achim von Arnim, published between 1805 and 1808 - it was given the heading, War Song of the Faith. In the $19^{\text {th }}$-century Germany, when the Reformation became a symbol of cultural and national freedom and Luther was honored as a political-religious-national saint (Nationalheiliger), this hymn was celebrated 
as a founding myth of the German culture (Fischer 2012:31, 32). It still evokes the connotation 'religion-culture-nation' in Germany.

Ein feste Burg was sung during the inauguration of a monument for Luther in Worms, Germany in 1868. The monument consists of a statue of Luther, surrounded by other statues that are all arranged in the shape of a stronghold or 'Burg'. The ideas reflected in the hymn form the foundation of the architectural conception of the monument (Fischer 2014:41-52). If not an example of concrete singing in public, it certainly is an example of singing set in concrete in 'the public square'! The first line of Ein feste Burg is also inscribed on the tower of the Castle Church in Wittenberg. It is meant to be read from a distance as one approaches the town and to be sounded in one's mind.

Much can be said of the strange ways in which this hymn was used in various contexts. Fischer (2014:21-24) refers to 'the shock of the Wirkungsgeschichte'. In 1917 (the $400^{\text {th }}$ anniversary of the Reformation), a German hymnologist, Wilhelm Nelle, wrote a propaganda piece in which he described Ein feste Burg as the 'song of battle fields' (Lied der Schlachtfelder) and in which he told the story of a British soldier in the First World War (19141918) who would have said that he found it very difficult to shoot at German soldiers who sang Ein feste Burg ist unser Gott while approaching them on the battle field (Fischer 2012:27, 39). Adaptations of the hymn, new interpretations, and parodies used to criticize views attached to the hymn are examples of how the 'Protestant heritage' is still present in the collective memory of people and is still taken further in the public sphere. According to Fischer (2014:223-236), this hymn has been serving a foundational, integrational, legitimizing, compensational, and protest function. Most of these functions play a role where hymns are used in the public sphere.

\section{Stille Nacht: Franz Xavier Gruber $(1818)-19^{\text {th }}$ to $21^{\text {st }}$ Century}

Accounts suggest that the legendary World War 1 Christmas truce of 1914 began with carol singing from the trenches on Christmas Eve. Silent Night played a prominent role. Written in the German language two centuries ago in Austria, the song spread across the world and has been implemented prominently in the public sphere in many countries and in many languages over 200 years. At various places on the battlefields, opposing forces sang it together in their own language. During the singing, the weapons fell silent at certain places almost providing for scenes of friendship and brotherhood 
(Verbrüderung) that was not in the interest of the military leadership (Herbst 2012:164). Singing carols such as Silent Night, certainly played a compensational role, therein that it served as comfort to the soldiers while far from their loved ones - they could imagine themselves being with their loved ones around the Christmas tree. It also played an integrational role - integration that went further than being integrated with the soldiers fighting on the same side only - enemies on the battlefield, but united through singing, because sound has the capacity to travel across spaces, fences, and trenches.

... and through walls...

\section{Dona Nobis Pacem (Text from the Agnus Dei)}

Mechtild Wenzel, a woman who lived in Magdeburg, East Germany in the times of the German Democratic Republic (GDR), once told me that, in the 1970s and 1980s, before the East-West-wall in Berlin came down, her church youth group would sing Dona nobis pacem (Give us peace) on their side of the wall and young people on the western side would join them (Wenzel 2019). With their singing, they spread the message of peace and resistance despite the division of the wall. According to Brödel (2019:67), Dona nobis pacem, sung as canon at the closing of the Friedensgebete (prayers for peace) in various places in the GDR, can be seen as the key song sung in the time of the peaceful revolution ${ }^{4}$.

\section{Komm, Herr, segne uns: Dieter Trautwein (1978)}

Komm, Herr, segne uns, dass wir uns nicht trennen (Come Lord, bless us, that we do not get separated) was a prominent hymn sung at the protest prayers, the prayers for peace (Friedensgebete or Montagsgebete), held during the late 1980s on Mondays at five in the Church of St. Nicholas (Nikolaikirche) in Leipzig in the GDR. Prayers for peace were also held in

4 Brödel (2019:67) relates the strange semi-political role that the organist and the organ in the Church of St. Nicholas had to play whenever it would be necessary. It had been agreed with the Nikolaikantor that he should immediately play with full organ in the event of a provocateur appearing in the course of the peace prayers who, through statements hostile to the state, would give the security forces present an excuse to intervene. When playing the organ at maximum volume, no spoken word is understandable. Fortunately, the plan never had to be executed. 
other churches in the GDR, but those in St. Nicholas had the strongest influence, growing stronger and becoming more significant in the course of 1989. Aimed towards 'spiritual community', this hymn became a signature element of the prayers for peace, which contributed to the 'peaceful revolution' (Ziemer 1997:192). It was sung with so much intensity, that visitors were drawn in by the singing. It is said that also members of the Stasi (secret police) later were heard humming this song. Even if it cannot be proved, there is no doubt that this song became part of the being of people who heard it repeatedly. It thus not only created community among the people in the church, but also played an integral function in touching and changing people on the outside. The singing of this song, together with Dona nobis pacem carried from the liturgical sphere out into the public square - contributed to a changed social consciousness and eventually also to the fall of the Berlin wall on November 9, 1989. Brödel (2019:62) refers to the triumph of economy over ideology - thus practical impulses for the fall of the wall, rather than changes in belief. However, the religious singing in a public service of prayer, taken out into the wider public sphere, certainly played a role to form community, to give hope, to strengthen people in difficult times, and to bring about changed views - and in doing so, contributed to bringing about a peaceful revolution.

One could ask why this song had such a strong influence. It became widely known after functioning as the closing song at the Kirchentag in Nürnberg in 1979. Despite fierce critique on the text, there are not many of the new religious songs written after the 1960s that became so popular and so widely used than this song (Stalmann 2013:9-10). Much of its popularity could be attributed to the tune - a flowing tune with not much rhythmic variation, easy to learn, and with something inherently contemplative that reflects the focus of the text: A prayer for peace and unity - a prayer requesting God to bless 'us'. The second part of the opening line is quite relevant: ...that we do not get separated. It could mean not to be separated from one another or separated from God. In the context of the East-West divide, however, it certainly received a layered meaning, becoming a prayer that the separation of Germany would end and that friends and family could be united after being separated for so long.

Witness to a very recent part of its Wirkungsgeschichte is reflected from the university service held in the Neustädter Church in Erlangen on May 17, 2020. Held on the first Sunday after the lockdown period of Covid-19, on 
which Gottesdienste in Bavaria were allowed with a full group of people, the service touched people deeply (Klek 2020). Sung as the closing hymn before the blessing - the only song sung by the full congregation - this song without doubt received new meaning for people being together and singing together for the first time after an extended period of being separated from one another.

\section{Struggle Songs from the Time of Apartheid, Functioning in a Democratic South Africa}

Struggle songs sung in the Apartheid era in South Africa, contributed to political change in this country. The female protestors singing at the Union Buildings in 1956 attracted widespread attention. Songs for worship were used to support the struggle, sometimes with wording adapted to give religious songs a political edge (Maluleke 2016). However, struggle songs from the political sphere were also sung in church buildings and during worship. Archbishop Desmond Tutu (Mayibuye Centre 2000:CD 1, nr. 4) explained the singing of freedom songs in church as a way of 'getting rid of the energy, the spirit of war' - in other words, lamenting, and singing about war 'before God', but also to bring the consciousness for what has to be changed, and indeed, to change people. This is related to the views expressed by Ziemer (1997:195) with regard to the prayers for peace in the Church of St. Nicholas in Leipzig: 'Where is the place where we can lament what we see, and lament our powerlessness before the conditions of our world, if not in worship?'

Well-known struggle songs (to mention a few) are Siyahamba (meaning, We go, better known as We are marching in the light of God), a song included in songbooks and hymnals worldwide and sung in churches over the world, and Senzeni $\mathrm{Na}$ (What have we done?), a protest song sung against the Apartheid regime, that is now sung at public gatherings to protest against violence and to lament the deaths of young women and girls - asking in a single sentence: 'What have we done'?' A third song, Nkosi Sikelel'

5 In the video recording by the TUKS Camerata to commemorate the death of a young woman (a student at UCT) in September 2019, the choir sings, sitting scattered in the hall, with seats randomly open between them, symbolizing the women and girls who were murdered and who thus were missing from the seats (University of Pretoria Camerata 2019). With seats open between the singers, this 
iAfrika (God bless Africa) now forms part of the National Anthem of South Africa. As a hymn, Nkosi Sikelel' iAfrika is a 'non-threatening prayer', but sung in the public sphere, the song took on new meaning - and still takes on new meaning. One of the most striking performances on YouTube is that of Ladysmith Black Mambazo in Montreux, Switzerland in 1989 (note the date!) (Ladysmith Black Mambazo 1989). In the public sphere of the concert hall, just before the last song, Joseph Shabalala announced unexpectedly: 'We'd like to pray with you now' and started singing Nkosi Sikelel' iAfrika. The entire group joined in. This prayer song and others worked politically subversively because it convinced the world of the inhumanity of the system of Apartheid: The audiences hearing the beauty of Ladysmith Black Mambazo's intricate vocal harmonies could hardly believe that these were the same kind of people as the unarmed protesters shown on the evening news being beaten and teargassed by the South African police (Coplan 2020). By blending Christian hymnody and isiZulu male polyphonic vocal traditions (the isicathamiya style of music) and performing these hymns in the public sphere with Black Mambazo, Joseph Shabalala Africanized the Christianity that he practiced. Coplan (2020) recalls listening to the group in Carnegie Hall in New York in 1988 and narrates that, 'for three uninterrupted hours...they kept the audience spellbound at the edge of their seats in awed, worshipful silence'. Joseph Shabalala was a good example of the influence that can be exerted in the public sphere. Coming from Ladysmith in KwaZulu-Natal, he started to tour the world, and with his group lived his faith through his singing. At his funeral - an official state funeral on February 22, 2020 President Ramaphosa (2020a) stated:

Where in the world did he not perform?...Despite his success he had his feet firmly on the ground: The ground right here in this community where he was born, and where he raised his family... [T]his community can hold its head up high for having produced this maestro, this leader and this man of deep and abiding faith. Indeed, our brother and father has left us to join the heavenly choir.

video took on new meaning during the Covid-19 period: The open seats could also depict the people who died during this period. 
This is indeed a strong tribute to a man's life ${ }^{6}$. The phrase 'to join the heavenly choir' used by the president at a funeral that was also an official state ceremony, could be seen as a sign of religion lived in the public sphere. The reference acquired extra meaning in the light of Ballantine's narrative where he asked Shabalala how he learnt his craft as a composer, to which Shabalala answered that, for a period of six months in 1964, he was every night visited in his dreams by a choir 'from above' that sang to him (Ballantine 2020).

\section{Thuma Mina}

The struggle song, Thuma Mina (Send me), was quoted by President Ramaphosa in his inaugural address as the new President of South Africa (Ramaphosa 2018; cf. Kloppers 2020:6-7). By using the expanded version of Hugh Masekela - a version with a sharp socio-political edge to it - he also recalled the memory of an African church chorus (Maluleke 2018). His aim was to inspire people to take individual responsibility, to serve, and to make personal sacrifices. Through the use of this song, the so-called Thuma Mina Campaign has begun. Originating from the biblical prophecies, Thuma Mina took on a strong political meaning in the public sphere: It represented honesty and commitment to root out corruption and it brought hope that things would be better during his term of office. By using 'sacred language', Ramaphosa

6 In this context, however, I find the use of the term 'maestro' pretentious. This term is usually used (pretentiously) in contexts of Western music making, to indicate the excellence and dominance of a skilled musician, where all attention is fixed on that person as an individual performer. It is, however, also used to impress listeners or readers, to show that the person using this title, has superior knowledge and has the authority to judge a specific musician. I argue that at this funeral, the term actually could distance the listeners from the real person being buried - indeed someone brilliant in music making, but also a master in leading people in performing the faith, and in drawing people into the faith in a very unassuming way. Shabalala's way of leading his group in a strong, self-effacing way, captivating his audience and making them a participating part of the performance, can serve as an excellent example of how a minister of religion is supposed to lead worship - constantly directing the public gaze away from the (often too important) self. 
meant to say: "Trust me, I am speaking the truth"7. I would say that much of the inspiration of the speech can be contributed specifically to the sound, the rhythm, and the meaning of Thuma Mina.

\section{We Shall Overcome}

Addressing the people of South Africa in various speeches during the Covid19 pandemic, Ramaphosa repeatedly referred to Christian symbols. By quoting Nkosi Sikel' iAfrika, he asked for God's blessing for the people of Africa and South Africa. In his speech on Maundy Thursday 2020 in which he announced the lockdown to be extended, he quoted the first line of yet another well-known struggle song, We Shall Overcome, just before ending with asking God's blessing. The original hymn, I'll Overcome Some Day, was published by Charles Albert Tindley in 1900 (Bobetsky 2014). It later became a key anthem of the Civil Rights Movement and has also functioned prominently in Apartheid South Africa, as well as in a variety of contexts of protest worldwide. It also had a prominent place in the prayers for peace in the Church of St. Nicholas, Leipzig in 1989. Describing a determining prayer for peace service held on September 25, 1989, which went over in a mass

7 Questions are asked whether he spoke 'the truth' by delivering on his promises, or whether he was hampered in doing so by people not sharing his views. Reflecting on Ramaphosa's upcoming SONA (pre-Corona speech) for 2020, Booyens wrote in The Conversation that the hope was 'that constructive new policy initiatives and definitive repair of damaged state institutions would emerge' (Booysens 2020). Interestingly she notes that now there are further signs that members of the ANC are 'still not singing from one hymn book' (Booyens 2020). Reference to the use of Thuma Mina takes on sinister tones when journalist Alec Hogg, in the introduction to an article, refers to Ramaphosa as being 'conspicuously silent on the scandal' of the abuse and subsequent death of 'a public servant man whose problems, ironically, flowed directly from the intervention at Eskom by then deputy, now SA president, Cyril Ramaphosa' (Hogg 2019). The article is about Dr Mark van der Riet, who was seen as the best coal specialist that South Africa had - a person who, while working full-time for Eskom, was awarded an unremunerated adjunct professorship at WITS University, supervising 33 post-graduate candidates 'in order to give back to society'. This is described as 'Ramaphosa's Thuma Mina only 13 years ahead of its time' (Hogg 2019). Hogg laments the lack of any acknowledgement of the courage of Van der Riet or the ultimate price he paid for 'membership of SA's Thuma Mina campaign long before it became fashionable' (Hogg 2019). 
demonstration, Geyer (2009) states that the changes they were speaking about in the service, were taking place at that moment - the service changed 'the reality' inside, and consequently also the 'reality outside'. He argues that especially the singing had a performative, a 'reality changing' function. It changed people who took a highly dangerous path and who feared the consequences, but through the singing the fear suddenly disappeared. Hope came about and they acted confidently as 'WE', written in capital letters. The song, 'We shall overcome', tied feelings and energies in the triad of hope ('we shall overcome'), the way ('we walk hand in hand'), and the goal ('we will live in peace') (Geyer 2009). Geyer's description of the power of the song certainly would be valid in the struggle in South Africa and also where the song was and is used over the world in situations of oppression and difficulty. Martin Luther King Jr. recited the words from We shall overcome in his final sermon delivered in Memphis on March 31, 1968, before his assassination. At his funeral, days later, it was sung by more than 50,000 people ${ }^{8}$.

By quoting this struggle song, Ramaphosa reminded people of very difficult times, times of struggle that lie behind, but also times that people have survived. He quoted the song, encouraging the people of South Africa, giving them strength, resilience, and hope. It is a good example of religion lived in the public sphere and the role that a song or hymn can play, even when quoted implicitly. Ending his speech, he said that the Easter weekend is a sacred time for many South Africans and that it therefore was a difficult time for all (Ramaphosa 2020b) ${ }^{9}$ :

8 The modern version of the song was said to have been sung first by tobacco workers during a 1945 cigar workers strike in Charleston, South Carolina. For an overview of its function in various contexts, see Wikipedia (2020).

9 Each year during Easter, several million members of the Zion Christian Church, the largest African initiated church in South Africa, travel per bus to Zion City at Moria, Polokwane for the annual Easter pilgrimage. Due to the Covid-19 pandemic, it was suspended in 2020. The timing of Ramaphosa's speech, to fall at $6.00 \mathrm{pm}$. on the evening of Maundy Thursday, clearly means that it had to function as comfort and also as 'substitute sermon', replacing the sermons that would be held over the weekend at Moria and in churches. The timing could also be a way of curbing protest against the extension of the lockdown, as the way in which it was done, was not approved by all. To the Christian message of Easter that of radical Resurrection - 'recovery' was added, which certainly was used to 
Yet the message of Easter is one we carry in our hearts tonight.

It is the message of hope, of recovery and of rebirth.

As we walk this road together, as we struggle to defeat this pandemic, we remain strong and united and resolved. Much is being asked of you, far more than should ever be asked. But we know that this is a matter of survival, and we dare not fail.

We shall recover.

We shall overcome.

May God bless South Africa and protect her people.

\section{President Obama Singing Amazing Grace (John Newton 1725-1807)}

A striking example of a hymn sung by a president of a very prominent country is that of President Obama, singing Amazing Grace on June 26, 2015, at the memorial service of a man who was shot during a service at the Emanuel African Methodist Episcopal Church in Charleston, nine days before. It was the memorial for the pastor of the church, who was also a Senator in the House of Representatives. A 21-year-old white supremacist man entered the church, sat for a while, and then opened fire with a handgun, killing nine people. The president's task was to offer solace, not just to the family and the people of Charleston, but to the nation (Buncombe 2017). His speech was much more than a speech - it was a sermon in the strongest sense of the word. It was the president of the USA, not afraid to show his faith in public, in order to strengthen people, to help them to mourn, to voice their sorrow, also to help them to forgive, to remind them of God's grace, and thus to give them hope. The start of the speech showed that it was more than a speech. He started by giving all praise and honor to God - and then continued (Obama 2015):

The Bible calls us to hope. To persevere and have faith in things not seen. 'They were still living by faith when they died', scripture tells us. 'They did not receive the things promised; They only saw them and welcomed them from a distance, admitting that they were foreigners and strangers on Earth'. We are here today to remember a

imply recovering or healing from illness, and even more so to include economic recovery. 
man of God who lived by faith. A man who believed in things not seen. A man who believed there were better days ahead.

He remembered the man's 'graciousness, his smile, his reassuring baritone', thus hinting to singing early in his speech. He also referred to the man's calling as a pastor, which was not confined to the walls of the congregation but was extended to the life and community in which the congregation resides. By also mentioning the names of the other people who were shot, Obama told the families that the nation shared in their grief. Later he referred to the grace surrounding Reverend Clem Pinckney and his Bible study group, '[T] he light of love that shone as they opened the church doors and invited a stranger to join in their prayer circle. Blinded by hatred, he [the perpetrator] failed to comprehend what Reverend Pinckney so well understood - the power of God's grace' (Obama 2015); emphasis added). Continuing, Obama then referred to his favorite hymn as 'the one we all know', quoting it: 'Amazing Grace, how sweet the sound that saved a wretch like me. I once was lost, but now I'm found; was blind but now I see' (Obama 2015). Expanding on what grace means, he took up dimensions reflected in the hymn: '[G]race is not earned. Grace is not merited. It's not something we deserve. Rather, grace is the free and benevolent favor of God - as manifested in the salvation of sinners and the bestowal of blessings' (Obama 2015). He then also took the aspect of blindness further, by saying that they had been blind as a nation: 'As a nation, out of this terrible tragedy, God has visited grace upon us, for he has allowed us to see where we've been blind. He has given us the chance, where we've been lost, to find our best selves ${ }^{10}$ (Obama 2015; emphasis added). Constantly speaking of 'us' and 'we', he took the people with him through aspects of the history of America, explaining how they came to where they were on that day and indicating the way they should go from there. Returning to the concept of 'grace', he said that it can change everything: 'Amazing grace. Amazing grace' (Obama 2015). He then started to sing the first two lines of the hymn, singing it $a$ Capella, with people joining in.

After the singing, he spoke with certainty: 'Clementa Pinckney found that grace' (Obama 2015), and he followed with the names of all other

10 This is a change in the theology of the hymn: From God finding 'us', to 'we finding our best selves'. 


\section{Elsabé C. Kloppers}

victims, adding after each name: '[Name] found that grace' (Obama 2015). After the names, he concluded, with the following: 'Through the example of their lives, they've now passed it on to us. May we find ourselves worthy of that precious and extraordinary gift, as long as our lives endure. May grace now lead them home' (Obama 2015). It comes as no surprise that he finally extended the wish for grace also to his country, the USA.

The presentation and the performance of the speech (or sermon) were so authentic and the message of forgiveness and grace so convincing, that it touched people deeply - also those watching it on television worldwide. I am convinced that the singing of the hymn contributed to the people feeling its message resonating in their bodies, bringing comfort in their muscles, hope in their sinews, and grace in their bones.

\section{Conclusion}

'It is important to always determine why hymns are sung, to which direction they point, and what the singing aims to accomplish' (Bubmann 2017:151). Taking this requirement seriously, I have briefly introduced the field of hymnology and have shown how hymnody builds bridges between personal faith, church, and public Christianity, while at the same time also forming bridges to the 'public sphere' - to function in a pluralist, secular, and postsecular society. I went on to discuss the functioning of hymns in various countries and in various contexts, showing that hymnody forms a part of the beliefs, symbols, self-concepts, values, identities, ideologies, and the collective cultural memory of people, and also functions as instruments of power, sets of myths, means of protest, and even weapons of war. I have argued that, through the centuries, hymns have been used in the public sphere for political and nationalist means, but that it has also played a positive role in comforting people, bringing people together, transforming people, and thus contributed to change in oppressive political and social systems.

\section{References}

Assmann, J. 1991. Der zweidimensionale Mensch: Das Fest als Medium des kollektiven Gedächtnisses. In Assmann, J. \& T. Sundermeier (eds.): 
Das Fest und das Heilige: Religiöse Kontrapunkte zur Alltagswelt. Gütersloh: Gütersloher Verlagshaus.

Ballantine, C. 2020. What inspired Joseph Shabalala's genius - in his own words. The Conversation. March 18, 2020. Available at: https:// theconversation.com/what-inspired-joseph-shabalalas-genius-in-hisown-words-132671?utm_medium=email\&utm_campaign=Latest $\% 20$ from\%20The\%20Conversation\%20for\%20March\%2018\%202020\%20 -\%201566614986\&utm_content=Latest $\% 20$ from $\% 20$ The $\% 20$

Conversation \%20for\%20March\%2018\%202020\%20-\%201566614986 +CID b6de84c37c37d90f7f36b0451fa2d236\&utm source=campaign monitor_africa\&utm_term=What $\% 20$ inspired\%20Joseph\%20Shabalal as\%20genius\%20-\%20in\%20his\%20own\%20words. (Accessed on March 19, 2020.)

Bobetsky, V. 2014. The complex ancestry of 'We Shall Overcome'. Choral Journal 57: 26-36.

Booyens, S. 2020. Cynical South Africans are unlikely to be moved by Ramaphosa's next big speech. The Conversation. February 7, 2020. Available at: https://theconversation.com/cynical-south-africans-areunlikely-to-be-moved-by-ramaphosas-next-big-speech-131399?utm_ medium=email\&utm_campaign=Latest $\% 20$ from $\% 20$ The $\% 20$ Conversa tion \%20for\%20February\%2010\%202020\%20-\%201531014606\&utm content=Latest $\% 20$ from $\% 20$ The $\% 20$ Conversation $\% 20$ for $\% 20$ Februar y\%2010\%202020\%20-\%201531014606+CID f6bbafa8088a699ed0c2 483a24759b6c\&utm_source=campaign_monitor_africa\&utm_term $=\mathrm{Cy}$ nical\%20South\%20Africans\%20are\%20unlikely $\% 20$ to $\% 20 \mathrm{be} \% 20 \mathrm{mov}$ ed\%20by\%20Ramaphosas\%20next\%20big\%20speech. (Accessed on March 7, 2020.)

Bosch, D. 1984. The roots and fruits of the Afrikaner civil religion. In Hofmeyr, J.W. \& W.S. Vorster (eds.): New faces of Africa. Pretoria: UNISA Press.

Brödel, C. 2019. Kirchenlied in der DDR. In Macht und Ohnmacht. Kirchenlied und Politik. Liturgie und Kultur: Zeitschrift der Liturgischen Konferenz für Gottesdienst, Musik und Kunst 3-2019: 61-68.

Bubmann, P. 2017. Freuden-Ode und Trauer-Choral. Hymnisches Singen als Ausdruck öffentlicher Religion. In Wabel, T., F. Höhne \& T. Stamer (eds.): Öffentliche Theologie zwischen Klang und Sprache: Hymnen als 
eine Verkörperungsform von Religion. Leipzig: Evangelische Verlagsanstalt.

Buncombe, A. 2017. Remembering Obama's 2015 speech at the Charleston shooting service, where he sang 'Amazing Grace'. The Independent. January 16, 2017. https://www.independent.co.uk/news/world/ americas/barack-obama-charleston-church-shooting-speech-in-fullvictoms-funeral-2015-amazing-grace-dylann-a7529641.html.

(Accessed on February 20, 2020.)

Coplan, D. 2020. Dance softly and carry a big voice: Understanding Joseph Shabalala. The Conversation. February 18, 2020. Available at: https://theconversation.com/dance-softly-and-carry-a-big-voice-understanding-joseph-shabalala-131939. (Accessed on February 22, 2020.)

De Groot, K. 2020. Verborgen aanwezigheid, een inleiding. In Goyvaerts, J.S., K. de Groot \& J. Pieper (eds.): Over de hardnekkige aanwezigheid van het Christendom. Utrechtse studies, Part XXIII. Almere: Parthenon.

Fischer, M. 2007. Großer Gott, wir loben dich. Populäre und traditionelle Lieder: Historisch-kritisches Liederlexikon. Available at: http://www. liederlexikon.de/lieder/grosser_gott_wir_loben_dich. (Accessed on November 5, 2019.)

Fischer, M. 2012. 'Ein feste Burg ist unser Gott' - Ein Lied im Wandel der Zeiten. In Bubmann. P. \& K. Klek (eds.): Davon ich singen und sagen will: Die Evangelischen und ihre Lieder. Leipzig: Evangelische Verlagsanstalt.

Fischer, M. 2014. Religion, Nation, Krieg: Der Lutherchoral 'Ein feste Burg ist unser Gott' zwischen Befreiungskriegen und Erstem Weltkrieg. Münster: Waxmann.

Franz, A. 2017. Nr 380 - Großer Gott, wir loben dich. In Franz, A., H. Kurzke \& C. Schäfer (eds.): Die Lieder des Gotteslob: Geschichte Liturgie - Kultur. Stuttgart: Katholisches Bibelwerk.

Franz, A. \& C. Schäfer 2019. Te Deum laudamus - Großer Gott, wir loben dich. In Macht und Ohnmacht: Kirchenlied und Politik. Liturgie und Kultur: Zeitschrift der Liturgischen Konferenz für Gottesdienst, Musik und Kunst 3-2019: 12-22.

Geyer, H. 2009. Keine Gewalt! Die Leipziger Friedensgebete und der 'Herbst '89'. In EKD Evangelische Kirche in Deutschland. 20 Jahre friedliche Revolution. III: Hintergründe. Available at: 
https://www.ekd.de/23412.htm. (Accessed on February 8, 2020.)

Graf, F.W. 2004. Die Wiederkehr der Götter: Religion in der modernen Kultur. München: Kaiser.

Herbst, W. 2012. 'Stille Nacht, heilige Nacht': Die Geburt eines Welterfolgs. In Bubmann. P. \& K. Klek (eds.): Davon ich singen und sagen will: Die Evangelischen und ihre Lieder. Leipzig: Evangelische Verlagsanstalt.

Holland, T. 2019. Dominion: The making of the Western mind. London: Little, Brown Book Group.

Hogg, A. 2019. Late Eskom exec Mark van der Riet: How state capture turned murderous. Biznews. January 8, 2019. Available at: https:// www.biznews.com/undictated/2019/01/08/late-eskom-exec-mark-vander-riet-state-capture-turned-murderous?fbclid=IwAR2Ynd2BcmYK PYPBvQOj8L5OkaFATz079ypzuTcP4DXGf76W1o5rT2BzuY.

(Accessed on May 8, 2019.)

Présente, A.F. 2019. Je Vous Salue Marie. YouTube. April 23, 2019. Available at: https://www.youtube.com/watch?v=iH8Pbcd4z80\& feature $=$ emb share \&fbclid=IwAR3UyCwvhFmeAUbyNKAEOpCX4x YUpyMgkNRntGyaaalCa1ZkcS0GquAlJ8U. (Accessed on February 20, 2020.)

Klek, K. 2012. 'Singen und Sagen' - Reformatorisches Singen als öffentlicher Protest. In Bubmann. P. \& K. Klek (eds.): Davon ich singen und sagen will: Die Evangelischen und ihre Lieder. Leipzig: Evangelische Verlagsanstalt.

Klek, K. 2020. Personal e-mail. May 19, 2020.

Kloppers, E. 2002. 'Die God is onse God...' Hymns, hymnals and the national identity of the Afrikaner - a critical assessment. Religion and Theology 9, 3\&4: 183-198.

Kloppers, E. 2012. People of God? Singing the Psalms as a reflection of identity - perspectives from South Africa and Scotland. NGTT 53, 3\&4: 160-168.

Kloppers, E. 2019. Grosser Gott, wir loben dich. Grote God, ons bring U eer - katoliek, protestants, ekumenies. Vir die Musiekleier 39: 104-121.

Kloppers, E. 2020. Performing the sacred - Aspects of singing and contextualisation in South Africa. HTS Theological Studies 76, 2: 9 pages. https://doi.org/10.4102/hts.v76i2.5477. 
Kurzke, H. 2010. Großer Gott, wir loben dich. In Kirchenlied und Kultur. Tübingen: Francke.

Ladysmith Black Mambazo. 1989. Nkosi Sikelel' iAfrika. YouTube. Available at: https://www.youtube.com/watch?time continue=38\&v= 288r0Mo1bFw\&feature=emb logo. (Accessed on March 20, 2020.)

Mager, I. 1986. Lied und Reformation: Beobachtungen zur reformatorischen Singbewegung in norddeutschen Städten. In Dürr, A. \& W. Killy (eds.): Das protestantische Kirchenlied im 16. und 17. Jahrhundert. Wiesbaden: Harrassowitz.

Maluleke, T. 2016. Zuma and co treading on the dreams of the poor. Sunday Independent. November 6, 2016. Available at: https://www.iol.co.za/ sundayindependent/zuma-and-co-treading-on-the-dreams-of-the-poor2087218. (Accessed on October 21, 2018.)

Maluleke, T. 2018. South Africa: The deep roots of Ramaphosa's 'Thuma Mina'. allAfrica.com. May 18, 2018. Available at: https:// allafrica.com/stories/201802210001.html. (Accessed on February 21, 2018.)

Mayibuye Centre 2000. South African Freedom Songs. CD 1 and 2. Quoted from CD booklet and sleeves. University of the Western Cape.

Marx, C. 1998. Im Zeichen des Ochsenwagens: Der radikale AfrikaanerNationalismus in Südafrika und die Geschichte der Ossewabrandwag. Münster: Lit Verlag.

Moodie, T.D.D. 1976. The rise of Afrikanerdom: Power, Apartheid, and the Afrikaner civil religion. Los Angeles: Berkeley.

Neufeld, M. 2006. Das Bild der Kirche im Singen der Gemeinde. Freiburg: Rombach.

Obama, B. 2015. President Obama delivers Eulogy. YouTube. June 26, 2015. Available at: https://www.youtube.com/watch?v=x9IGyidtfGI. (Accessed on February, 20, 2020).

Ramaphosa, M.C. 2018. State of the Nation Address. South African Government. February 16, 2018. Available at: https://www.gov.za/ speeches/president-cyril-ramaphosa-2018-state-nation-address-16-feb2018-0000. (Accessed February 28, 2018.)

Ramaphosa, M.C. 2020a. Eulogy by President Cyril Ramaphosa at the funeral of Joseph Shabalala. Eyewitness News. February 20, 2020. https://ewn.co.za/2020/02/22/eulogy-by-president-cyril-ramaphosa-atthe-funeral-of-joseph-shabalala. (Accessed on February 23, 2020.) 
Ramaphosa, M.C. 2020b. Extension of Coronavirus Covid-19 lockdown to the end of April. South African Government. April 9, 2020. Available at: https://www.gov.za/speeches/president-cyril-ramaphosa-extensioncoronavirus-covid-19-lockdown-end-april-9-apr-2020-0000. (Accessed on April 10, 2020.)

Söffner, J. 2018. Wenn die Geisteswissenschaften eine grosse Zukunft haben wollen, müssen sie wieder mehr erzählen. Neue Zürcher Zeitung. August 27, 2018. Available at: https://www.nzz.ch/feuilleton/ erzaehlen-heisst-leben-ld.1405108. (Accessed on February 1, 2020.)

Stalmann, J. 2013. 170. Komm, Herr, segne uns. In Herbst, W \& I. Seibt (eds.): Liederkunde zum Evanglischen Gesangbuch. Part 18. Göttingen: Vandenhoeck \& Ruprecht.

University of Pretoria Camerata. 2019. Tuks Camerata - Senzeni Na. YouTube. September 4, 2019. Available at: https://www.youtube.com/ watch?v=DIBeoCOHR7g. (Accessed on March 20, 2020.)

Wenzel, M. 2019. Personal conversation regarding her earlier experiences in Magdeburg. August 2, 2019, in Halle, Germany.

Wikipedia. 2020. We shall overcome. Available at: https://en.wikipedia.org/ wiki/We_Shall_Overcome. (Accessed on March 20, 2020).

Ziemer, J. 1997. Gottesdienst und Politik - Zur Liturgie der Friedensgebete. In Morath, R. \& W. Ratzmann (eds.): Herausforderung: Gottesdienst. Beiträge zu Liturgie und Spiritualität. Vol. 1. Leipzig: Evangelische Verlagsanstalt.

Prof Elsabé C. Kloppers Department of Philosophy, Practical and Systematic Theology University of South Africa kloppec@unisa.ac.za 